\title{
Kelayakan dan Strategi Pengembangan Usaha Keju Natural Di Rumah Keju Jogja Daerah Istimewa Yogyakarta
}

\author{
Feasibility and Development Strategy of Natural Cheese Business \\ in Rumah Keju Jogja Daerah Istimewa Yogyakarta
}

\section{Richa Puspita Dewi*, Budiarto, dan Antik Suprihanti}

Program Studi Agribisnis Jurusan Agribisnis Fakultas Pertanian Universitas

Pembangunan Nasional "Veteran" Yogyakarta

JL. SWK (Lingkar Utara) Condong Catur Yogyakarta Indonesia

*Email korespondensi: richapuspitadewi2298@gmail.com.

Diterima tanggal : 12 Juni 2021 ; Disetujui tanggal : 29 Juni 2021

\begin{abstract}
The purposes of this study were 1) to describe the perfomance of the natural cheese business, 2) to analyze the feasibility natural cheese business, 3) to find the best development strategy natural cheese business. The research method was descriptive model. The type of research was a case study. The method of respondents had taken by purposive method. The type data was primary and secondary data. The method of collecting data was interview, observation, and documentation. To describe the perfomance of natural cheese business in Rumah Keju Jogja was using descriptive method. Feasibility business was using benefit cost ratio. To analyze the development strategy was using IFE (Internal Factor Evaluation), EFE (External Factor Evaluation), matrix IE (Internal External), SWOT (Strength, Weaknesses, Opportunity, Threat), and with AHP (Analytical Hierarchy Process) model. The results of the research showed that 1) natural cheese business in Rumah Keju Jogja have a good location, online and offline marketing, have a halal certificate from MUI and has been running management fuctions 2) the feasibility study of natural cheese business in Rumah Keju Jogja was not feasible 3) the best development strategy for natural cheese business in Rumah Keju Jogja was market penetration by using facebook or instagram and other promotion media to increase the sales.
\end{abstract}

Keywords : development strategy, feasibility, natural cheese, performance

\begin{abstract}
ABSTRAK
Penelitian ini bertujuan untuk 1) menganalisis Keragaan usaha keju natural, 2) menganalisis kelayakan Usaha keju natural, 3) menetapkan prioritas strategi pengembangan usaha yang dapat diterapkan untuk mengembangkan Usaha keju natural. Metode dasar penelitian yang digunakan adalah metode deskriptif. Metode pelaksanaan dalam penelitian ini menggunakan metode studi kasus. Metode penentuan responden penelitian menggunakan metode purposive. Jenis data yang digunakan yaitu data primer dan sekunder. Metode pengumpulan data yaitu dengan wawancara, observasi, dan studi pustaka. Teknik analisis data yang digunakan dalam penelitian ini yaitu untuk keragaan dianalisis secara deskripsi,
\end{abstract}


kelayakan usaha dianalisis menggunakan analisis benefit cost ratio dan strategi pengembangan usaha dianalisis menggunakan metode IFE, EFE, SWOT, IE dan Metode Analytical Hierarcy Process (AHP). Berdasarkan penelitian yang telah dilakukan didapatkan hasil penelitian 1). Usaha keju natural di Rumah Keju Jogja memiliki lokasi produksi yang strategis, pemasaran yang dilakukan secara online dan offline, memiliki sertifikat halal dari MUI dan sudah melakukan fungsi fungsi manajemen dalam usahanya. 2). Usaha keju natural di "Rumah Keju" Jogja selama tidak layak dilaksanakan dengan nilai b/c ratio sebesar 0,38 3) strategi pengembangan usaha yang menjadi prioritas untuk pengembangan usaha keju natural di Rumah Keju Jogja adalah penetrasi pasar melalui meningkatkan promosi melalui penggunaan facebook dan instagram yang lebih optimal atau melalui media promosi lainnnya untuk meningkatkan penjualan.

Kata kunci : strategi pengembangan, kelayakan usaha, , keju natural, keragaan

\section{PENDAHULUAN}

Salah satu usaha menengah kecil yang berada di Yogyakarta adalah usaha Rumah Keju Jogja yang beralamat di Jl. Plemburan, Gg. Cucakrowo No.4, Sariharjo, Daerah Istimewa Yogyakarta. Rumah Keju Jogja merupakan sebuah bentuk usaha bersama yang didirikan pada tahun 2018. Sesuai dengan nama usahanya, Rumah Keju Jogja adalah usaha rumah tangga yang mengolah susu sapi segar menjadi berbagai macam aneka keju natural. Saat ini sudah ada 7 jenis produk keju yang dihasilkan oleh Rumah Keju Jogja yaitu Hallomi, Mozarella,

Ricotta, Cream Cheese, dan Cheddar.

Tabel 1. Omset penjualan Usaha Rumah Keju Jogja tahun 2019

\begin{tabular}{lrr}
\hline \multicolumn{1}{c}{ Bulan } & $\begin{array}{c}\text { Penjualan } \\
(\text { Rp) }\end{array}$ & $\begin{array}{c}\text { Laba (Rugi) } \\
(\text { Rp) }\end{array}$ \\
\hline Januari & 1.377 .055 & 474.948 \\
Februari & 1.485 .040 & $(3.169 .139)$ \\
Maret & 2.660 .290 & $(1.258 .930)$ \\
April & 2.689 .925 & $(1.660 .165)$ \\
Mei & 4.712 .284 & 1.115 .424 \\
Juni & 3.496 .226 & $(1.980 .124)$ \\
Juli & 6.767 .502 & $(763.448)$ \\
Agustus & 8.106 .680 & 1.386 .138 \\
September & 7.752 .170 & $(2.796 .230)$ \\
Oktober & 4.277 .825 & 477.525 \\
November & 4.010 .751 & $(3.933 .534)$ \\
Desember & 5.244 .650 & 1.095 .888 \\
\hline Sumber $:$ Ruma
\end{tabular}

Sumber : Rumah Keju Jogja (2019).

Keterangan $:(\ldots .)=$. Rugi 
Dewi, et.al., Kelayakan dan Strategi Pengembangan Usaha Keju Natural Di...

Berdasarkan pada Tabel 1, dapat diketahui bahwa omset dan volume penjualan keju di usaha Rumah Keju Jogja dalam 1 tahun sangat fluktuatif dan masih mengalami kerugian di beberapa bulan. Hal ini disebabkan karena perhitungan masalah biaya produksi yang telah mereka keluarkan yang kurang rinci dan diskon untuk harga produk yang tidak melalui perhitungan, terkadang membuat keuntungan menjadi berkurang bahkan rugi. Oleh karena itu, diperlukan analisis kelayakan usaha pada usaha Rumah Keju Jogja.

Walaupun masih tergolong baru, usaha pengolahan ini tetap berjalan karena prospek ke depan produk olahan keju dan turunannya sangat tinggi seiring dengan kesadaran masyarakat terhadap pola konsumsi makanan sehat saat ini. Namun faktanya penjualan masih berfluktuatif. Hal ini juga diduga disebabkan masih adanya permasalahan pada lingkungan internal dan eksternal yang mempengaruhi berkembangnya Rumah Keju Jogja. Oleh karena itu, diperlukan strategi pengembangan usaha pada usaha Rumah Keju Jogja supaya usaha ini bisa berkembang dengan baik.

Dalam lingkungan internal yang menjadi kekuatan dari Rumah Keju Jogja adalah produk yang dihasilkan natural artinya tanpa bahan pengawet dan $100 \%$ terbuat dari susu. Oleh karena itu, Rumah Keju Jogja sebagai penghasil keju natural lebih sehat untuk dikonsumsi oleh masyarakat Indonesia. Sedangkan kelemahannya adalah sumberdaya manusia yang kurang terampil sehingga masih terjadi kegagalan produksi. Hal itu disebabkan karena pembuatan keju pada jenis tertentu yang tidak mudah, menyebabkan terjadinya kagagalan produksi pada produk - produk tertentu. Sehingga menjadi kerugian tersendiri bagi Rumah Keju Jogja.

Faktor kelemahan juga masih terlihat dalam aspek pemasaran. Saat ini pemasaran pada usaha Rumah Keju Jogja masih menggunakan sistem made by order via media sosial. Media sosial yang digunakan untuk menerima orderan adalah Instagram dan Whatsapp. Sistem made by order yang diterapkan menyebabkan produksinya selama ini masih tergantung dengan jumlah orderan yang masuk. Namun, Rumah Keju Jogja juga tetap memiliki stok produk dalam jumlah yang terbatas. 
Dalam lingkungan eksternal yang masih menjadi ancaman dapat dilihat dari sektor pemasok susu sebagai bahan baku utama pembuatan keju. Pemasok susu Rumah Keju Jogja berasal dari satu Kelompok ternak yang sudah dipercaya kualitasnya, sehingga dalam penerimaan susu dari peternak kepada Rumah Keju Jogja tidak dilakukan uji kualitas. Hal itu dikarenakan masih terbatasnya alat yang dimiliki oleh Rumah Keju Jogja, sehingga hal tersebut terkadang menjadi salah satu penyebab terjadinya kegagalan pada saat produksi keju.

Selain itu faktor ancaman juga datang dari adanya pesaing baik dari sesama pengusaha keju natural seperti Mazaraat Artisan Cheese dan dari keju olahan seperti prochizz, kraft, dan Cheddar membuat persaingan antar usaha semakin ketat. Dilihat dari segi harga karena keju yang dihasilkan merupakan keju natural, maka tentu harganya lebih tinggi dibandingkan dengan merk keju olahan sehingga perlu adanya edukasi kepada masyarakat agar lebih memilih mengkonsumsi keju natural yang lebih sehat dibandingkan dengan keju olahan. Hal tersebut juga membuat pangsa pasar Rumah Keju Jogja sempit, walaupun makanan keju ini sehat. Hanya masyarakat yang mengetahui tentang keju natural yang mau mengkonsumsinya. Berdasarkan uraian latar belakang tersebut, maka penelitian ini bertujuan untuk menganalisis keragaan, kelayakan dan startegi pengembangan usaha usaha keju natural di Rumah Keju Jogja.

\section{METODE PENELITIAN}

Metode dasar penelitian yang digunakan dalam penelitian adalah deskriptif. Metode pelaksanaan penelitian yang digunakan adalah penelitian studi kasus. Tujuan studi kasus adalah untuk memberikan gambaran secara mendetail tentang latar belakang, sifat-sifat serta karakter-karakter yang khas dari kasus, ataupun status dari individu, yang kemudian, dari sifat-sifat khas di atas akan dijadikan suatu hal yang bersifat umum. Penelitian ini dilakukan di Rumah Keju Jogja yang merupakan satu - satunya usaha di Kabupaten Sleman yang berbentuk kelompok yang rutin mengadakan pelatihan pembuatan keju.

Metode penentuan responden yang digunakan dalam penelitian ini adalah metode purposive. Metode purposive adalah teknik pengambilan sampel dengan 
Dewi, et.al., Kelayakan dan Strategi Pengembangan Usaha Keju Natural Di...

pertimbangan tertentu agar data lebih representatif (Sugiyono, 2017). Adapun yang menjadi responden pada penelitian ini adalah Ketua, Wakil Ketua, Bendahara, manager produksi dan manager marketing. Jenis dan sumber data yang digunakan dalam penelitian ini adalah data kuantitatif yang didukung data kualitatif yang diperoleh dari dalam perusahaan maupun luar perusahaan dalam bentuk data primer dan data sekunder. Metode pengumpulannya adalah observasi, wawancara, Dokumentasi dan pencatatan, Kuisoner dan FGD (focus group discussion). Metode pengujian instrumennya adalah uji validitas dan uji reliabilitas. Teknik analisis data yang digunakan dalam penelitian ini yaitu untuk keragaan dianalisis secara deskripsi, kelayakan usaha dianalisis menggunakan analisis benefit cost ratio dan strategi pengembangan usaha dianalisis menggunakan metode IFE, EFE, SWOT, IE dan Metode Analytical Hierarcy Process (AHP).

\section{HASIL DAN PEMBAHASAN}

Usaha Rumah Keju Jogja merupakan sebuah kelompok usaha bersama (KUB) yang dirintis oleh ibu - ibu dari komunitas kreasi jemariku. Usaha yang dilakukan ini adalah usaha pengolahan keju berupa keju natural. Dalam mengelola usahanya ini masih mengalami banyak permasalahan baik dari faktor internal maupun eksternal perusahaan. Oleh karena itu perlu dilakukan analisis terhadap keragaan usaha, kelayakan usaha dan pemilihan strategi pengembangan usaha yang tepat agar Usaha keju natural di Rumah Keju Jogja dapat berkembang dan bertahan.

\section{Analisis Keragaan Usaha}

Analisis keragaan usaha keju natural di Rumah Keju Jogja melihat keempat aspek sesuai dengan teori kasmir dan jakfar (2016) yaitu dilihat dari aspek produksi, aspek manajemen, aspek pasar dan juga aspek hukum. Aspek Hukum usaha keju natural di Rumah Keju jogja ini telah bersertifikat halal dari MUI dengan nomor 15120029500418. Namun, usaha ini masih belum memiliki izin BPOM. Hal itu dikarenakan belum memiliki tempat produksi sendiri. Saat ini, lokasi produksi usahanya masih menyatu dengan rumah ketua dari usaha 
Rumah Keju Jogja. Seharusnya sebuah usaha dibidang olahan makanan, izin BPOM sangatlah penting untuk meingkatkan kepercayaan konsumen terhadap produk yang dihasilkan

Menurut Handjojo (2017) Analisis produksi dan operasi dalam penelitian meliputi pemilihan lokasi, bahan baku yang digunakan, proses produksi, kebutuhan bangunan, mesin dan peralatan. Dilihat dari aspek produksi usaha keju natural di Rumah Keju Jogja secara pemilihan lokasi usaha sudahlah tepat, namun ketidakpastian kapan mereka melakukan produksi inilah yang menjadi kendala. Rumah Keju Jogja dalam melakukan produksi keju natural ini selalu melihat jumlah orderan yang masuk dan stock yang ada, sehingga pelaksanaan produksi tidak terjadwal dengan baik. Seharusnya dalam melaksanakan produksi terjadwal dengan baik agar kuantitas produknya lebih stabil. Kemudian untuk peralatan yang mereka gunakan merupakan peralatan yang sederhana, sehingga untuk melakukan produksi sangat terbatas kapasitasnya. Seharusnya Rumah Keju Jogja mulai memperbaharui peralatannya agar kapasitas alatnya bisa lebih banyak dan hasil kualitas produknya lebih baik lagi.

Dilihat dari aspek manajemen juga masih memiliki kekurangan. Di dalam aspek manajemen terdapat 4 fungsi yang seharusnya dilakukan. Keempat fungsi tersebut adalah perencanaan, pengorganisasian, pelaksanaan, dan pengawasan. Pada fungsi perencanaan ini Usaha Rumah Keju Jogja pada awal berdirinya melakukan perencanaan dasar seperti pembuatan struktur organisasi dan pembagian tugas. Namun, setelah berjalannya waktu dalam menjalani usahanya lebih sering tidak melakukan perencanaan secara matang karena mereka selalu berprinsip mengikuti alur dan keadaan saja. Kemudian, untuk fungsi pengorganisasian ini pihak pengurus dari usaha Rumah Keju Jogja sudah terdapat struktur organisasi. Namun, struktur organisasi yang mereka miliki masih kurang terlaksana dengan baik. Hal ini dikarenakan masih adanya pengurus yang bekerja tidak sesuai tugas dan fungsinya. Biasanya Rumah Keju Jogja membuat rencana produksi dalam satu minngu dengan melihat jumlah orderan yang masuk dan stock yang ada. Usaha ini sendiri dalam melakukan pengawasan yaitu pada saat produksi dilakukan dengan mengawasi pekerjaan karyawan. 
Dewi, et.al., Kelayakan dan Strategi Pengembangan Usaha Keju Natural Di...

Dilihat dari aspek pasar yang dimiliki oleh Rumah Keju Jogja, untuk wilayah pasar keju natural ini sendiri masih di dalam wilayah Yogyakarta dan sekitarnya. Penjualannya sendiri dilakukan dengan dua cara yaitu online dan offline. Penjualan offline dilakukan di Rumah Keju Jogja ini sendiri dengan membuka outlet kecil didepan teras rumah dan mengikuti pameran-pameran. Penjualan secara online menggunakan facebook dan instagram. Pelaksanaan penjualan online ini sendiri mereka belum memanfaatkan ecomerce seperti shopee, tokopedia, atau buka lapak. Selain itu Usaha Rumah Keju Jogja juga belum memiliki website sendiri untuk mempromosikan produknya.

Setelah melakukan observasi pengamatan berdasarkan 4 aspek yang ada menunjukkan bahwa keragaan pada usaha keju natural di Rumah Keju Jogja masih mengalami banyak permasalahan. Hal itu dikarenakan usaha Rumah Keju Jogja yang masih tergolong usaha kecil atau UMKM. Menurut Ariani (2017) sektor UMKM di Indonesia mempunyai ciri - ciri yaitu kegiatan usaha tidak terorganisir dengan baik, tidak mempunyai izin usaha yang lengkap, pola kegiatan usaha tidak teratur dengan baik dan kebijakan pemerintah tidak sampai pada sektor ini. Oleh karena itu diperlukan adanya peningkatan dan perbaikan di dalam usaha keju Natural di Rumah Keju Jogja yang masih tergolong usaha kecil.

\section{Analisis Kelayakan Usaha}

Analisis kelayakan usaha menggambarkan layak atau tidaknya suatu usaha. Titik berat analisis kelayakan adalah aspek keuangan terutama lalu lintas uang yang terjadi selama kegiatan usaha (Lakamisi, 2016). Analisis kelayakan yang digunakan dalam penelitian ini adalah menggunakan $\mathrm{B} / \mathrm{C}$ ratio. Dalam menghitung $\mathrm{B} / \mathrm{C}$ ratio diperlukan adanya hasil keuntungan dan juga total biaya yang dikeluarkan. Perhitungan B/C ratio disini melihat dalam produksi pada bulan Januari - Desember 2019 dan April - Oktober tahun 2020.

Berdasarkan tabel 2 nilai $\mathrm{B} / \mathrm{C}$ ratio merupakan perbandingan antara benefit atau keuntungan dengan cost atau biaya. Berdasarkan rata-rata keuntungan dan rata-rata biaya produksi pada bulan Januari 2019 sampai Oktober 2020 maka nilai $\mathrm{B} / \mathrm{C}$ ratio sebesar 0,38 . Apabila nilai $\mathrm{B} / \mathrm{C}$ ratio kurang dari 1 maka usaha 
tidak layak dilaksanakan. Hal itu dikarenakan usaha ini yang masih baru dan lebih berfokus pada kegiatan pelatihan pembuatan keju atau edukasi. Menurut penelitian dari Cahyanto (2016), sebuah industri perlu dianalisa kelayakannya apakah usaha tersebut layak atau tidak. Jika usaha layak berarti usaha tersebut dapat dilanjutkan ke tingkat yang lebih tinggi. Namun sebaliknya jika usaha tersebut tidak layak maka perlu dilakukan perbaikan untuk mempertahankan dan mengembangkan usahanya. Oleh karena itu perlu adanya strategi untuk mempertahankan dan mengembangkan usaha.

Tabel. 2. Nilai B/C Ratio per Bulan

\begin{tabular}{lrrr}
\hline Bulan & $\begin{array}{c}\text { Keuntungan } \\
(\text { Rp) }\end{array}$ & Total Biaya (Rp) & B/C Ratio \\
\hline Januari 2019 & 474.948 & 902.107 & 0,52 \\
Februari 2019 & 3.169 .139 & 4.654 .179 & $-0,68$ \\
Maret 2019 & 1.258 .930 & 3.919 .220 & $-0,32$ \\
April 2019 & 1.660 .165 & 4.350 .090 & $-0,38$ \\
Mei 2019 & 1.115 .424 & 3.596 .860 & 0,31 \\
Juni 2019 & 1.980 .124 & 5.476 .350 & $-0,36$ \\
Juli 2019 & 763.448 & 7.530 .950 & $-0,1$ \\
Agustus 2019 & 1.386 .138 & 6.720 .542 & $-0,2$ \\
September 2019 & 2.796 .230 & 10.548 .400 & $-0,26$ \\
Oktober 2019 & 477.525 & 3.800 .300 & 0,12 \\
November 2019 & 3.933 .534 & 7.944 .285 & $-0,5$ \\
Desember 2019 & 1.095 .888 & 4.148 .762 & 0,2 \\
April 2020 & 4.759 .074 & 4.338 .826 & 1,1 \\
Mei 2020 & 5.631 .714 & 4.217 .186 & 1,33 \\
Juni 2020 & 6.548 .214 & 5.631 .586 & 1,16 \\
Juli 2020 & 4.832 .214 & 4.001 .186 & 1,21 \\
Agustus 2020 & 9.695 .914 & 4.550 .786 & 2,13 \\
September 2020 & 4.041 .614 & 3.894 .286 & 1,04 \\
Oktober 2020 & 3.208 .914 & 3.191 .886 & 1,05 \\
\hline & Total & & 7,37 \\
\hline & Rata - Rata & & 0,38 \\
\hline Sumber : Rumah Keju & & &
\end{tabular}

Sumber : Rumah Keju Jogja (2019 - 2020)

\section{Analisis Strategi Pengembangan Usaha}

Pada saat ingin menentukan strategi pengembangan usaha, maka terdapat beberapa tahap. Tahap tersebut adalah melakukan input faktor internal dan juga 
Dewi, et.al., Kelayakan dan Strategi Pengembangan Usaha Keju Natural Di...

faktor eksternal, melakukan pencocokan, dan keputusan. Setelah melakukan input maka akan diperoleh nilai dari matrik EFI dan EFE.

Tabel 3. Matriks Aktual Evaluasi Faktor Internal Rumah Keju Jogja

\begin{tabular}{|c|c|c|c|}
\hline Faktor Internal & Bobot & Rating & Skor \\
\hline \multicolumn{4}{|l|}{ Kekuatan } \\
\hline \multicolumn{4}{|l|}{ Produksi dan Operasi } \\
\hline Produk Natural & 0,11 & 3,6 & 0,396 \\
\hline Produk bervariasi & 0,09 & 3,6 & 0,324 \\
\hline Memiliki sertifikat halal MUI & 0,11 & 3,8 & 0,418 \\
\hline \multicolumn{4}{|l|}{ Manajemen } \\
\hline Hubungan baik antara pengurus dan karyawan & 0,09 & 3,6 & 0,324 \\
\hline $\begin{array}{l}\text { Memiliki facebook dan instagram sebagai forum } \\
\text { komunitas dan pemasaran }\end{array}$ & 0,09 & 3,6 & 0,324 \\
\hline \multicolumn{4}{|l|}{ Kelemahan } \\
\hline \multicolumn{4}{|l|}{ Produksi dan Operasi } \\
\hline Alat produksi masih sederhana & 0,08 & 2,2 & 0,176 \\
\hline Life time produk yang tidak panjang & 0,08 & 1,8 & 0,144 \\
\hline \multicolumn{4}{|l|}{ Manajemen } \\
\hline SDM Terbatas & 0,09 & 1,8 & 0,162 \\
\hline Sistem pembukuan masih sederhana & 0,08 & 1,4 & 0,112 \\
\hline \multicolumn{4}{|l|}{$\begin{array}{l}\text { Keuangan } \\
\text { Kena }\end{array}$} \\
\hline Keterbatasan modal & 0,09 & 1,8 & 0,162 \\
\hline \multicolumn{4}{|l|}{ Pemasaran } \\
\hline Pemasaran yang belum intensif & 0,09 & 1,6 & 0,144 \\
\hline Total & 1,0 & & 2,686 \\
\hline
\end{tabular}

Sumber : Data Primer diolah (2020)

Berdasarkan matrik EFI indikator yang memiliki kekuatan dan kelemahan paling tinggi adalah sudah memiliki sertifikat halal dan alat produksi yang masih sederhana. Sertifikat halal yang dimiliki usaha Rumah Keju Jogja berdampak pada kepercayaan konsumen terhadap produk keju yang dihasilkan. oleh karena itu, dengan adanya sertifikat halal dari MUI dapat mendukung kegiatan pemasaran yang dilakukan oleh usaha Rumah Keju Jogja. Sedangkan kelemahan tertinggi adalah alat produksi yang masih sederhana. Oleh karena itu, produk yang dihasilkan setiap kali produksi kapasitasnya terbatas dan kegiatan produksi tidak efisen dan efektif. 
Jurnal Dinamika Sosial Ekonomi, 22 (1) : 88-102

Tabel 4. Matriks Aktual Evaluasi Faktor Eksternal (EFE)

\begin{tabular}{|c|c|c|c|}
\hline Faktor Eksternal & Bobot & Rating & Skor \\
\hline \multicolumn{4}{|l|}{ Ancaman } \\
\hline \multicolumn{4}{|l|}{ Persaingan } \\
\hline Banyaknya Pesaing & 0,11 & 2,6 & 0,286 \\
\hline Ekonomi & & & \\
\hline Harga bahan baku yang tidak stabil & 0,11 & 2,8 & 0,308 \\
\hline Sosbud \& Demografi & & & \\
\hline $\begin{array}{l}\text { Kualitas bahan baku yang belum } \\
\text { konsisten }\end{array}$ & 0,14 & 2,6 & 0,364 \\
\hline \multicolumn{4}{|l|}{ Peluang } \\
\hline Sosbud \& Demografi & & & \\
\hline Tren makanan sehat & 0,14 & 3,4 & 0,476 \\
\hline $\begin{array}{l}\text { Banyaknya supplier bahan baku di } \\
\text { Daerah }\end{array}$ & 0,14 & 3,6 & 0,432 \\
\hline Politik, Hukum dan Pemerintah & & & \\
\hline $\begin{array}{l}\text { Adanya Dukungan pemerintah } \\
\text { Teknologi }\end{array}$ & 0,13 & 2,8 & 0,364 \\
\hline Perkembangan teknologi & 0,13 & 2,6 & 0,338 \\
\hline Saran promosi yang tersedia & 0,13 & 2,6 & 0,338 \\
\hline Total & 1,0 & & 2,906 \\
\hline
\end{tabular}

Sumber : Data Primer diolah (2020)

Berdasarkan matriks EFE indikator yang menjadi ancaman dan peluang tertinggi adalah kualitas bahan baku yang belum konsisten dan tren makanan sehat. Usaha ini dalam melakukan produksinya masih mengalami berbagai kegagalan produksi yang diakibatkan oleh kualitas bahan baku yang belum konsisten. Adanya faktor peluang tren makanan sehat juga perlu dimanfaaatkan oleh usha Rumah Keju Jogja dengan melakukan promosi pada media sosial mengenai produk keju natural yang sehat.

Matriks Internal-External dapat digunakan sebagai alat untuk mengetahui posisi perusahaan dalam pertumbuhan dan persaingan suatu industri bisnis serta memberikan alternatif strategi bagi perusahaan. Penentuan posisi perusahaan dalam Matriks IE diperoleh dari kombinasi total nilai Matriks IFE dan Matriks EFE. Matriks IE membagi posisi perusahaan ke dalam sembilan sel yang terdiri dari tiga alternatif strategi yaitu Grow and Build, Hold and Maintain, dan Harvest and Divest. Hasil kedua matriks tersebut akan menjadi matriks IE dalam menentukan posisi usaha Rumah Keju Jogja saat ini. Berikut ini pemetaan matriks IE berdasarkan dengan hasil EFI dan EFE. 
Dewi, et.al., Kelayakan dan Strategi Pengembangan Usaha Keju Natural Di...

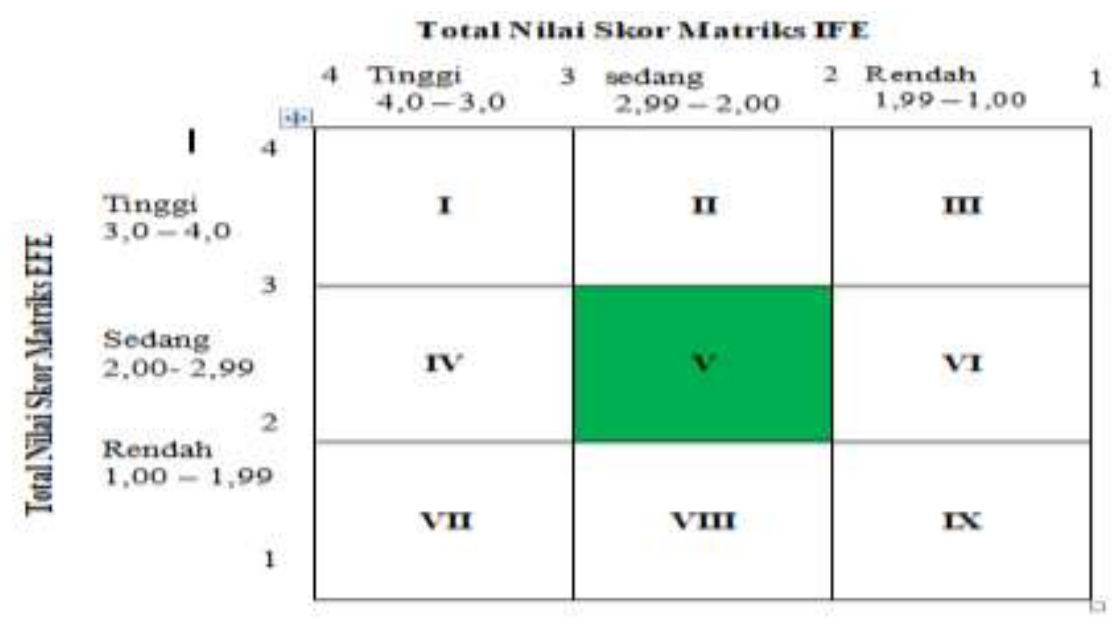

Gambar 1. Aktual Matrik IE Rumah Keju Jogja

Sumber : Data Primer diolah (2020)

Hasil dari pemetaan tersebut usaha Rumah Keju Jogja terletak pada sel V. Arti dari sel $\mathrm{V}$ ini menunjukkan bahwa posisi perusahaan berada pada posisi bertahan dan pelihara. Oleh karena itu, strategi yang dilakukan apabila usaha berada pada sel $\mathrm{V}$ yaitu strategi pengembangan produk dengan strategi penetrasi pasar. Menurut David (2016) Penetrasi pasar adalah strategi yang berusaha untuk meningkatkan pangsa pasar untuk produk/jasa di pasar saat ini melalui usaha pemasaran yang lebih besar. Penetrasi pasar mencangkup meningkatkan jumlah tenaga penjual, jumlah belanja iklan, menawarkan promosi penjualan yang ekstensif, atau meningkatkan usaha publisitas. Sedangkan strategi pengembangan produk merupakan strategi yang mencari peningkatan penjualan dengan memperbaiki atau memodifikasi produk/jasa saat ini.

Setelah dilakukan analisis dan perhitungan terhadap faktor internal dan eksternal dengan menggunakan analisis IFE dan EFE serta diketahui posisi perusahaan dengan matrik IE. Kemudian dilakukan tahapan pemanduan dengan matriks SWOT. Matriks SWOT ini dibangun berdasarkan faktor - faktor eksternal maupun internal yang terdiri dari peluang, ancaman, kekuatan dan kelemahan (Siregar, 2012). Hasil perumusan dikelompokkan menjadi 4 strategi yaitu SO, WO, ST dan WT. 


\begin{tabular}{|c|c|c|}
\hline & \begin{tabular}{ll} 
& \multicolumn{1}{c}{ Strength (S) } \\
1. & Produk Natural \\
2. & Produk Beragam \\
3. & Hubungan baik antar \\
pengurus dan karyawan \\
4. & Sudah Sertifikasi Halal \\
5. & Memiliki facebook dan \\
instagram sebagai forum \\
komunitas dan pemasaran
\end{tabular} & 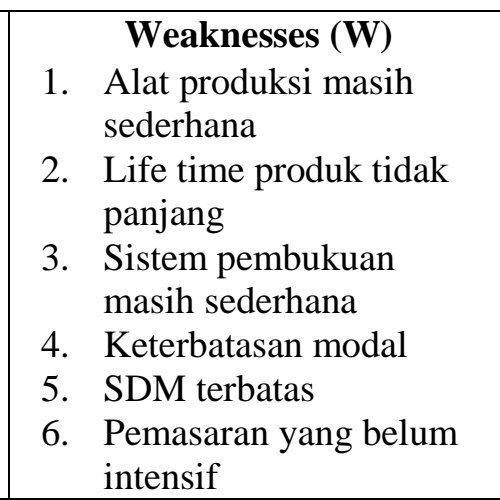 \\
\hline 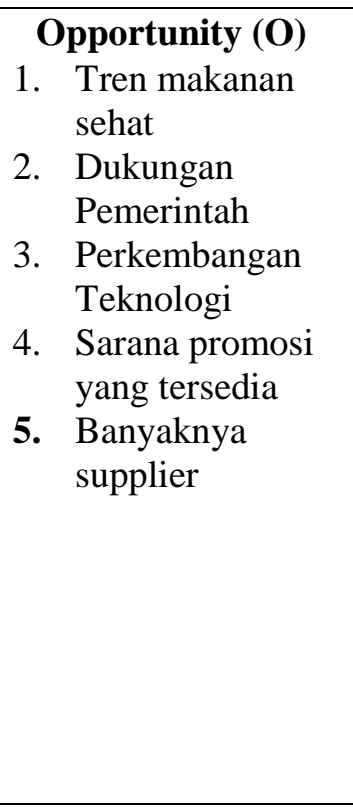 & \begin{tabular}{ll} 
& \multicolumn{1}{c}{ Strategi SO } \\
1. & meningkatkan promosi \\
melalui penggunaan \\
facebook dan instagram \\
yang lebih optimal atau \\
melalui media promosi \\
lainnnya untuk \\
meningkatkan penjualan \\
(S1,S4, S5,O1 dan O4) \\
2. Meningkatkan kualitas \\
produk dengan \\
pemanfaatan teknologi \\
(S1, S2 dan O3). \\
3. Menjaga kualitas produk \\
dengan menerapkan \\
strandar penerimaan susu \\
dari peternak (S1, S2 dan \\
O5).
\end{tabular} & 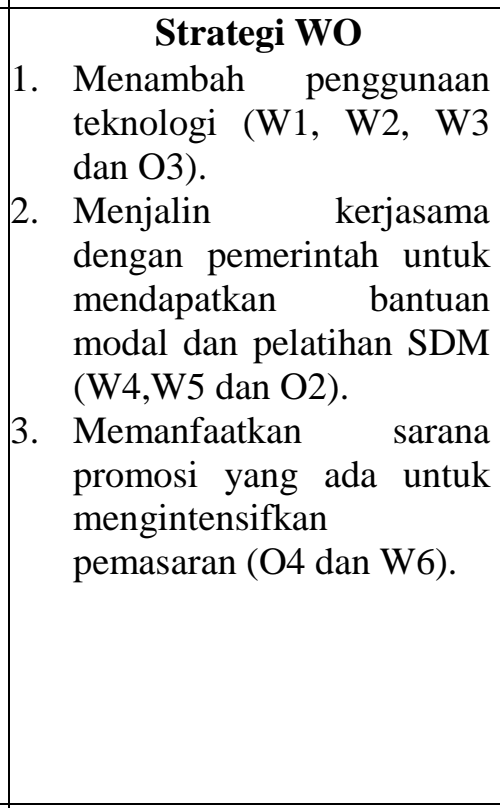 \\
\hline $\begin{array}{ll}\text { Threat (T) } \\
\text { 1. } & \text { Banyaknya } \\
\text { pesaing } \\
\text { 2. }\end{array}$ & $\begin{array}{l}\text { Strategi ST } \\
\text { 1.Meningkatkan mutu produk } \\
\text { agar dapat bersaing dan } \\
\text { sesuai dengan standar } \\
\text { pasar (S1, S2 dan T1). }\end{array}$ & $\begin{array}{l}\text { Strategi WT } \\
\text { 1. Perbaikan sistem } \\
\text { produksi dan SDM untuk } \\
\text { mengatasi persaingan } \\
\text { (W5,W6 dan T1). }\end{array}$ \\
\hline
\end{tabular}

Gambar 2. Rumusan Strategi Alternatif dengan Matriks SWOT Sumber : Data Primer diolah (2020)

Berdasarkan hasil anlisis SWOT didapat hasil rata - rata SO adalah 0,37, rata - rata WO adalah 0,28 , rata - rata ST adalah 0,32 dan rata - rata WT adalah 0,47. Skor tertinggi diperoleh pada strategi SO. Oleh karena itu, strategi yang digunakan adalah strategi didalam SO. Strategi SO yang sesuai dengan hasil matrik IE penetrasi pasar dan pengembangan produk adalah meningkatkan promosi melalui penggunaan facebook dan instagram yang lebih optimal atau 
Dewi, et.al., Kelayakan dan Strategi Pengembangan Usaha Keju Natural Di...

melalui media promosi lainnnya untuk meningkatkan penjualan, Meningkatkan kualitas produk dengan pemanfaatan teknologi dan Menjaga kualitas produk dengan menerapkan strandar penerimaan susu dari peternak.

Tahapan yang terakhir dalam menentukan prioritas strategi pengembangan usaha bagi Rumah Keju Jogja adalah tahap pengambilan keputusan. Alternatif strategi yang telah dihasilkan melalui analisis IE dan dicocokkan dengan Matrik SWOT akan di prioritaskan menggunakan metode Analytical Hyrarcy Process (AHP).

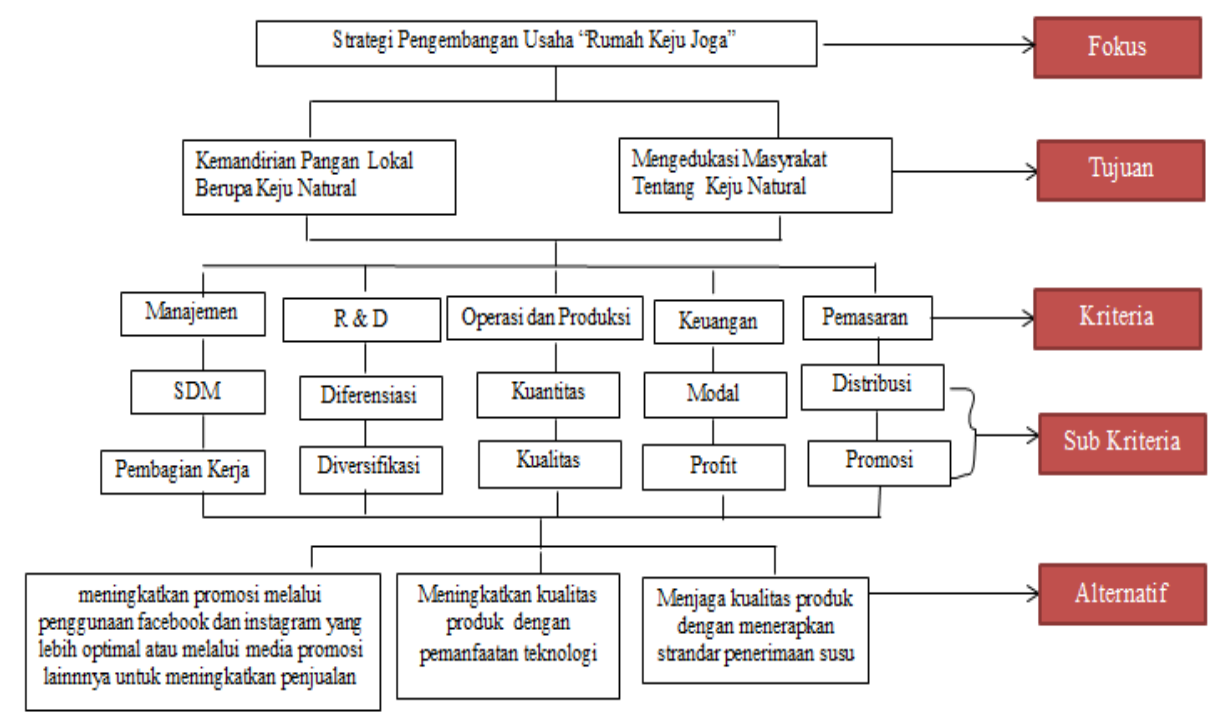

Gambar 3. Hirarki Priotitas Strategi Pengembangan Usaha Rumah Keju Jogja Sumber : Data Primer diolah (2020)

Berdasarkan Gambar 3, Hasil matriks IE menjadi Fokus dalam menentukan alternatif strategi prioritas. Tujuan yang diambil berdasarkan tujuan dari Usaha "Rumah Keju Jogja". Kriteria yang dgunakan berdasarkan Faktor internal yaitu manajemen, R\&D, Operasi dan Produksi, keuangan dan Pemasaran. Sub kriteria yang diambil berdasarkan keadaan di lapangan dilandasi dari faktor internal.

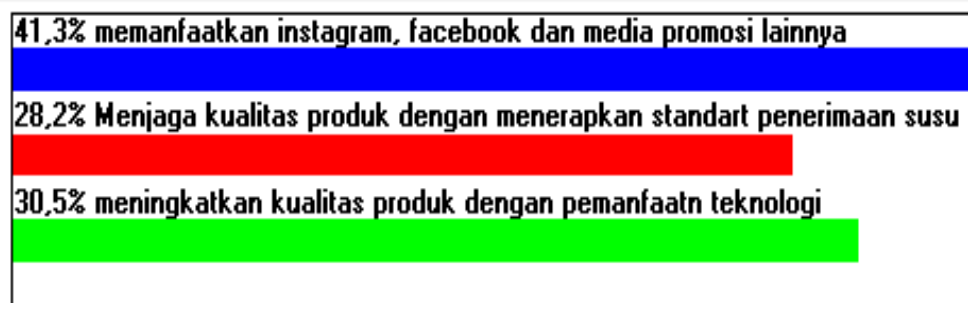


Dari hasil pembobotan AHP diperoleh strategi yang paling prioritas yang bisa diterapkan oleh Rumah Keju Jogja adalah strategi penetrasi pasar dengan meningkatkan promosi melalui penggunaan facebook dan instagram yang lebih optimal atau melalui media promosi lainnnya untuk meningkatkan penjualan.Menurut penelitian dari Nanda (2018) menyatakan bahwa dengan memanfaatkan media sosial untuk promosi bisnis, seperti adanya e-commerce juga dapat membantu para pelaku bisnis untuk meningkatkan penjualan. Ecommerce juga dapat menjangkau seluruh sisi dunia. Setelah penjualan meningkatkan diharapkan dapat meningkatkan skala produksi. Selain itu, proses produksi dapat berjalan lebih efesien.

\section{SIMPULAN}

Usaha keju natural di Rumah Keju Jogja memiliki lokasi produksi yang strategis, pemasaran yang dilakukan secara online dan offline, memiliki sertifikat halal dari MUI dan sudah melakukan fungsi - fungsi manajemen dalam usahanya. Usaha keju natural di Rumah Keju Jogja tidak layak untuk dijalankan. Strategi pengembangan usaha yang dapat dilakukan untuk usaha Keju natural di Rumah Keju Jogja adalah penetrasi pasar dengan meningkatkan promosi melalui penggunaan facebook dan instagram yang lebih optimal atau melalui media promosi lainnnya untuk meningkatkan penjualan.

Usaha keju natural di Rumah Keju Jogja sebaiknya melakukan perbaikan dalam pelaksanaan manajemen sesuai tugas dan fungsinya masing - masing dan meningkatkan kapasitas produksi melalui peningkatan alat produksi yang digunakan agar usaha ini dapat lebih berkembang. Usaha keju natural di Rumah Keju Jogja ini layak dilaksanakan sehingga sebaiknya terus dikembangkan melalui perbaikan pencatatan pembukuan yang lebih tertata dan perhitungan biaya produksi yang lebih rinci. Usaha keju natural di Rumah Keju Jogja sebaiknya memprioritaskan strategi penetrasi pasar dengan meningkatkan promosi melalui penggunaan facebook, instagram yang lebih optimal atau melalui media promosi lainnnya untuk mengembangan usahanya. 
Dewi, et.al., Kelayakan dan Strategi Pengembangan Usaha Keju Natural Di...

\section{DAFTAR PUSTAKA}

Cahyanto, Teguh. (2016). Analisis Kelayakan Dan Strategi Pengembangan Usaha Pada Industri Minyak Atsiri di PT. XYZ. Institut Pertanian Bogor. Bogor.

Ariani dan Utomo, Muhammad. (2017). Kajian Strategi Pengembangan Usaha Mikro Kecil Dan Menengah (UMKM) Di Kota Tarakan. Jurnal Organisasi dan Manajemen, 13 (2) : 99-118.

David, Fred. (2016). Manajemen Strategik : Suatu Pendekatan Keunnggulan Bersaing. Jakarta : Salemba Empat.

Handjojo, Suwito dkk. (2017). Analisis Kelayakan Bisnis Usaha Teh Papua (Vernonia Amygdalina). Jurnal Manajemen IKM, 12 (2) : 145-150

Kasmir dan Jakfar. (2003). Studi Kelayakan Bisnis Edisi Revisi. Jakarta : Kencana Penada Media Group.

Lakamisi, Hayati dan Usman, Rukiaty. (2016). Analisis Finansial dan Strategi Pengembangan Usaha Kecil Menengah (UMKM) Kacang Vernis. Jurnal Ilmiah Agribisnis dan Perikanan, 9 (2) : 58-64.

Nanda, Anisa Yusrin. (2018). Analisis strategi pemasaran yang efektif Bagi Pengguna E-Commerce. Jurnal Manajemen dan Inovasi (MANOVA), 1 (1) : 11-19.

Sugiyono. (2017). Metode Penelitian Kuantitatif, kualitatif dan R\&D. Bandung : Alfabeta.

Siregar, Gustina. (2012). Analisis Kelayakan dan Strategi Pengembangan Usaha Ternak Sapi Potong. Jurnal Agrium, 17 (3) : 192-200. 